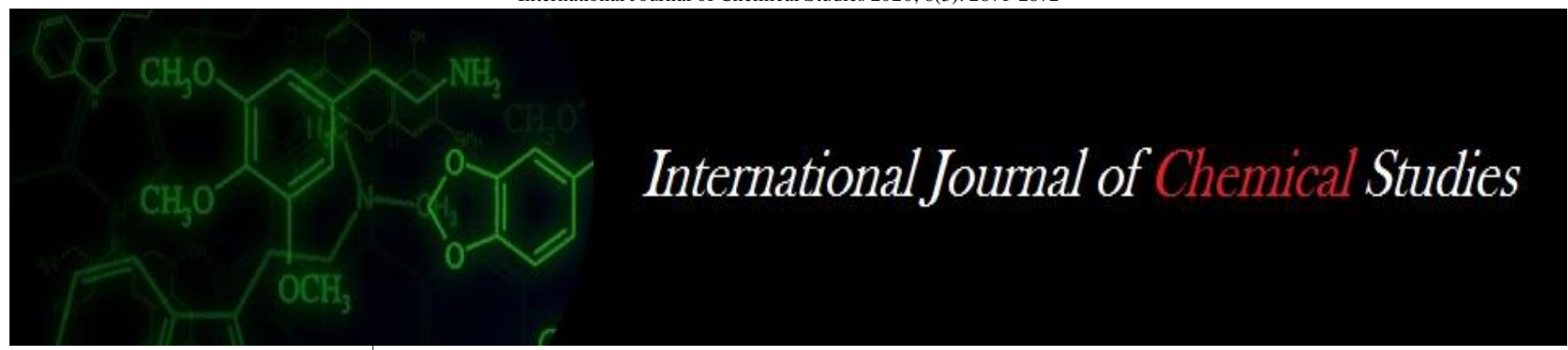

P-ISSN: 2349-8528

E-ISSN: 2321-4902

www.chemijournal.com

IJCS 2020; 8(3): 2871-2872

(C) 2020 IJCS

Received: 06-03-2020

Accepted: 08-04-2020

Dr. S Avudaithai

Ph. D., Professor and Head,

Department of Agronomy Anbil

Dharmalingam Agricultural

College and Research Institute,

Navalur Kuttapattu,

Tiruchirappalli, Tamil Nadu,

India

S Somasundaram

Department of Agronomy, Anbil

Dharmalingam Agricultural

College and Research Institute,

Navalur Kuttapattu,

Tiruchirappalli, Tamil Nadu, India
Corresponding Author: Dr. S Avudaithai

Ph. D., Professor and Head,

Department of Agronomy Anbil

Dharmalingam Agricultural

College and Research Institute,

Navalur Kuttapattu,

Tiruchirappalli, Tamil Nadu,

India

\section{Evaluation of varieties and irrigation levels on the preformance of finger millet in sodic soil}

\section{Dr. S Avudaithai and S Somasundaram}

DOI: https://doi.org/10.22271/chemi.2020.v8.i3ap.9647

\begin{abstract}
Two field experiments were conducted at Anbil Dharmalingam Agricultural College and Research Institute, Tiruchirappalli during 2018 and 2019. The main plot treatments consisted of three varieties viz; $\mathrm{V}_{1}$ : TRY ${ }_{1}, \mathrm{~V}_{2}$ : Paiyur 2 and $\mathrm{V}_{3}$ : $\mathrm{CO}(\mathrm{Ra}) 15$. The sub-plot treatments were $\mathrm{I}_{1}$ : IW/CPE ratio of $0.4, \mathrm{I}_{2}$ : IW/CPE ratio of $0.6, \mathrm{I}_{3}$ : IW/CPE ratio of 0.7 , and $\mathrm{I}_{4}$ : IW/CPE ratio of 0.8 . The seasons were Kharif. The design used was split plot design with three replications. The study indicated that the variety, $\mathrm{CO}(\mathrm{Ra}) 15$ with IW/CPE ratio 0.8 and 0.7 recorded the highest grain yield and on par.
\end{abstract}

Keywords: Finger millet, varieties, irrigation regimes, grain yield

\section{Introduction}

Finger millet is an important minor millet crop grown in India and has the superiority of having higest productivity among millets. Selection of varieties plays a key role in case of finger millet. Varieties show wide variation in their yielding abililty when grown in different environments. Now-a-days, finger millet has to be grown in water scarcity condition. Hence optimum irrigation scheduling is needed to economise the water use. As a predominantly rainfed kharif crop, finger millet does not require irrigation. However, irrigation at tillering and flowering is conducive for realising higher yields, wherever long dry spells in the season are experienced. During rabi season, the crop requires 2-3 irrigations coinciding with tillering, flowering and grain filling stages. Drainage is more important in kharif season, at times of heavy rainfall. Hence with a view to evaluate the varieties and suitable irrigation regimes, this study was undertaken.

\section{Materials and methods}

The experiments were conducted at the college farm, Anbil Dharmalingam Agricultural College and Research Institute, Tiruchirappalli during 2018 and 2019. The treatments included main plot treatments of varieties viz; $\mathrm{V}_{1}$ : TRY $1, \mathrm{~V}_{2}$ : Paiyur 2 and $\mathrm{V}_{3}$ : $\mathrm{CO}(\mathrm{Ra}) 15$. The sub-plot treatments consisted of $\mathrm{I}_{1}$ : IW/CPE ratio of $0.4, \mathrm{I}_{2}$ : IW/CPE ratio of $0.6, \mathrm{I}_{3}$ : IW/CPE ratio of 0.7 , and $\mathrm{I}_{4}$ : IW/CPE ratio of 0.8 . The design followed was split plot design. The seasons were Kharif. The soil type was sodic soil.

\section{Results and discussion}

The varieties recorded height on par with each other. The varieties are non-significant. The irrigation schedules have recorded plant height on par with each other during the first year. During 2019, the varieties, CO(Ra)15 and TRY 1 have recorded plant height on par with each other. The variety Paiyur 2 has recorded plant height which is the lowest. Among the irrigation regimes, IW/CPE ratio of 0.8 has recorded significantly the highest value for plant height. This is followed by IW/CPE ratio of 0.7 .

During 2018, the variety TRY 1 has recorded 8 number of tillers per plant. It is on par with other varieties. They are non-significant. The irrigation regimes are non-significant. In the year 2019 , the variety $\mathrm{CO}(\mathrm{Ra}) 15$ recorded significantly the highest number of tillers per plant. This confirms the findings of Abhishek (2018) ${ }^{[1]}$. Among the irrigation regimes, IW/CPE ratio of $0.8 \mathrm{had}$ recorded significantly the highest number of tillers per plant. 
During 2018, the variety, $\mathrm{Co}(\mathrm{Ra}) 15$ recorded 6-8 fingers per earhead. It is on par with other varieties, TRY 1 and Paiyur 2. Similarly irrigation regime of $I_{1}$ recorded highest number of fingers per ear head. However, it was on par with $\mathrm{I}_{2}$.

In the year 2019, number of fingers per ear head was on par with varieties TRY 1 and $\mathrm{CO}(\mathrm{Ra}) 15$. This was followed by Paiyur 2. Among the irrigation regimes, IW/CPE ratio of 0.7 and 0.8 were on par.

In the year 2018, Paiyur 2 recorded significantly the highest number of grains per finger. And it was on par with variety $\mathrm{CO}(\mathrm{Ra}) 15$. The irrigation regimes were non-significant with regard to number of grains per finger. During 2019, the varieties $\mathrm{CO}(\mathrm{Ra}) 15$ and TRY 1 were on par. This is followed by Paiyur 2. Among the irrigation regimes, IW/CPE ratio of 0.7 and 0.8 were on par and superior over IW/CPE ratio of 0.4 and 0.6 .

The ear head weight was $8.9 \mathrm{~g}$ with the variety $\mathrm{CO}(\mathrm{Ra}) 15$ which was significant in the year 2018. The irrigation regimes had no effect on the ear head weight. In 2019 also, the variety, $\mathrm{Co}(\mathrm{Ra}) 15$ recorded significantly the highest value for ear head weight. The irrigation regimes, 0.7 and 0.8 are on par and significantly superior over 0.4 and 0.6 .
The thousand grain weight was on par with the varieties. The irrigation levels have no significant effect on thousand grain weight in the year, 2018. During 2019, the varieties are nonsignificant. Among the irrigation regimes, IW/CPE ratio of 0.7 and 0.8 are on par and significantly superior over IW/CPE ratio of 0.4 and 0.6 .

Regarding the grain yield, Paiyur 2 recorded significantly the highest grain yield of $3758 \mathrm{kgha}^{-1}$ in 2018. During 2019, the variety, $\mathrm{CO}(\mathrm{Ra}) 15$ recorded the highest grain yield. This was followed by the variety, TRY 1 . This confirms the findings of Munirathnam and Kumar (2015) ${ }^{[3]}$, Divya et al. (2017) ${ }^{[2]}$ and Abhishek (2018) ${ }^{[1]}$. Among the irrigation regimes, IW/CPE ratio of 0.8 recorded significantly the highest grain yield followed by IW/CPE ratio of 0.7 .

Regarding the stover yield, Paiyur 2 recorded significantly the highest yield of $7882 \mathrm{kgha}^{-1}$. This was followed by TRY 1 which was on par with $\mathrm{CO}(\mathrm{Ra}) 15$ in 2018. IW/CPE ratio of 0.4 recorded the highest stover yield of $8230 \mathrm{kgha}^{-1}$. During 2019 , the stover yield followed the same trend as that of grain yield.

Hence it can be concluded that the variety, $\mathrm{CO}(\mathrm{Ra}) 15$ with IW/CPE ratio of 0.7 , and 0.8 recorded significantly the highest grain yield and on par.

Table 1: Effect of varieties and irrigation levels on the plant height, number of tillers per plant and number of fingers per ear head

\begin{tabular}{|c|c|c|c|c|c|c|}
\hline \multirow{2}{*}{ Treatments } & \multicolumn{2}{|c|}{ Plant Height (cm) } & \multicolumn{2}{|c|}{ No. of tillers /Plant } & \multicolumn{2}{|c|}{ No. of fingers/ear head } \\
\hline & 2018 & 2019 & 2018 & 2019 & 2018 & 2019 \\
\hline \multicolumn{7}{|c|}{ Main Plot } \\
\hline $\mathrm{V}_{1}: \mathrm{TRY}_{1}$ & 89.8 & 99.8 & 8.0 & 7.9 & 6.3 & 6.6 \\
\hline $\mathrm{V}_{2}$ : Paiyur 2 & 95.2 & 92.1 & 8.0 & 7.9 & 6.2 & 5.7 \\
\hline $\mathrm{V}_{3}: \mathrm{Co}(\mathrm{Ra}) 15$ & 96.0 & 104.4 & 6.0 & 9.6 & 6.8 & 7.0 \\
\hline SEd & - & 2.2 & - & 0.3 & -- & 0.2 \\
\hline $\mathrm{CD}(0.05)$ & NS & 6.2 & NS & 0.8 & NS & 0.6 \\
\hline \multicolumn{7}{|c|}{ Sub-Plot } \\
\hline $\mathrm{I}_{1}: \mathrm{IW} / \mathrm{CPE}: 0.4$ & 92.8 & 90.6 & 8.0 & 7.0 & 6.9 & 5.7 \\
\hline $\mathrm{I}_{2}: \mathrm{IW} / \mathrm{CPE}: 0.6$ & 95.6 & 92.0 & 8.0 & 7.4 & 6.7 & 6.3 \\
\hline $\mathrm{I}_{3}:$ IW/CPE: 0.7 & 92.0 & 104.5 & 7.0 & 9.2 & 6.2 & 7.0 \\
\hline I4: IW/CPE: 0.8 & 94.0 & 108.0 & 7.0 & 10.2 & 6.4 & 6.8 \\
\hline SEd & - & 1.6 & - & 0.2 & 0.2 & 0.2 \\
\hline $\mathrm{CD}(0.05)$ & NS & 3.3 & NS & 0.5 & 0.5 & 0.4 \\
\hline
\end{tabular}

Table 2: Effect of varieties and irrigation levels on the yield attributes and yield

\begin{tabular}{|c|c|c|c|c|c|c|c|c|c|c|}
\hline \multirow{2}{*}{ Treatments } & \multicolumn{2}{|c|}{ No. of grains/finger } & \multicolumn{2}{|c|}{ Ear head wt (g) } & \multicolumn{2}{|c|}{ Test Weight (g) } & \multicolumn{2}{|c|}{ Grain yield $\left(\mathrm{kgha}^{-1}\right)$} & \multicolumn{2}{|c|}{ Stover yield $\left(\mathrm{kgha}^{-1}\right)$} \\
\hline & 2018 & 2019 & 2018 & 2019 & 2018 & 2019 & 2018 & 2019 & 2018 & 2019 \\
\hline \multicolumn{11}{|c|}{ Main Plot } \\
\hline $\mathrm{V}_{1}$ & 220 & 338 & 5.0 & 8.3 & 4.9 & 4.8 & 2787 & 2990 & 5586 & 4276 \\
\hline $\mathrm{V}_{2}$ & 306 & 293 & 8.4 & 7.8 & 4.9 & 4.8 & 3758 & 2296 & 7882 & 3284 \\
\hline $\mathrm{V}_{3}$ & 304 & 354 & 8.9 & 9.1 & 5.0 & 5.0 & 3010 & 3601 & 6165 & 5150 \\
\hline SEd & 16.0 & 11.0 & 0.1 & 0.2 & - & 0.1 & 95.0 & 148 & 382 & 211 \\
\hline $\mathrm{CD}(0.05)$ & 46.0 & 31.0 & 0.3 & 0.6 & NS & 0.2 & 265.0 & 410 & 1062 & 587 \\
\hline \multicolumn{11}{|c|}{ Sub-Plot } \\
\hline $\mathrm{I}_{1}$ & 273 & 298 & 7.8 & 6.7 & 5.0 & 4.6 & 3433 & 2041 & 8230 & 2919 \\
\hline $\mathrm{I}_{2}$ & 272 & 300 & 7.0 & 7.4 & 4.8 & 4.4 & 3306 & 2727 & 6519 & 3900 \\
\hline $\mathrm{I}_{3}$ & 275 & 352 & 8.0 & 9.9 & 4.9 & 5.2 & 2798 & 3310 & 4915 & 4733 \\
\hline $\mathrm{I}_{4}$ & 287 & 363 & 7.0 & 9.7 & 5.1 & 5.3 & 3202 & 3771 & 6513 & 5393 \\
\hline SEd & - & 8.0 & - & 0.2 & - & 0.1 & - & 125 & 416 & 179 \\
\hline $\mathrm{CD}(0.05)$ & NS & 17.0 & NS & 0.5 & NS & 0.2 & NS & 263 & 875 & 376 \\
\hline
\end{tabular}

\section{References}

1. Abhishek MJ. Response of finger millet (Eleusine Coracana L. Gaertn) varieties to different levels of NPK under sodic soil condition. M.Sc. (Ag) thesis submitted to Anbil Dharmalingam Agricultural College and Research Institute, Tiruchirappalli, 2018.

2. Divya G, Vani KP, Babu PS, Devi KBS. Impact of cultivars and integrated nutrient management on growth, yield and economics of summer pearl millet. Int. J. App. Pure Sci. Agri., 2017; 3(7):64-68.

3. Munirathnam P, Kumar KA. Response of white ragi varieties to nitrogen under rainfed situation in vertisols of Andhra Pradesh. Annals of Plant and Soil Research. 2015; 17(2):142-145. 